\title{
GUSTAV STRESEMANN: THE PROBLEM OF POLITICAL LEADERSHIP IN THE WEIMAR REPUBLIC ${ }^{1}$
}

\author{
"I wanted to be the bridge between the old and the new Germany..."
}

\section{Gustav Stresemann to Wilhelm Kahl, March I 3, $1929^{2}$}

As a persistent critic of the German Revolution of November 9, 19 I 8 , and of the Weimar Republic, the Conservative publicist Arthur Moeller van den Bruck frequently denounced what he called the "republic without republicans". "The Republic in which we are living", he wrote, "is a joyless republic. Is it really a republic? Is it not still a monarchy that has merely been deprived of its emblems? Is not this thing which has no symbol on which one can fasten belief, is it not monarchy in its deepest humiliation?" 3 The questions that Moeller van den Bruck was asking for Conservatives were being asked, in their own way, by men through the spectrum of intellectual and political life: by men on the Left who wanted a Communist or Socialist republic, by men of the Right who wanted a popular constitutional monarchy, by the few who wanted the status quo, and by the many who wanted some kind of progressive change in public life. Not least among the questioners was Gustav Stresemann, the young leader of the new German People's Party. ${ }^{4}$

1 Paper read at the annual meeting of the Canadian Historical Association, Edmonton, June 6, 1958.

2 Gustav Stresemann Papers, microfilm container $3164 /$ serial 741 $1 /$ frames $174722-33$, National Archives, Washington, D.C. Reference to the film will hereafter be made in the

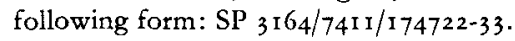

3 [Arthur] Moeller van den Bruck, Konservativ (Berlin, n.d.), pp. 6-7, I I, 20-I. Even Hugo Preuss referred to the Republic as an improvised democracy : Fritz Hartung, Zur Geschichte der Weimarer Republik, in: Historische Zeitschrift CLXXXI, 3 (June, r956), p. 58 I.

${ }^{4}$ For the literature on Stresemann see the bibliographical note in Hans W. Gatzke, Stresemann and the rearmament of Germany (Baltimore, 1954); the same author's bibliographical article, The Stresemann Papers, in: Journal of Modern History XXVI, I (Mar., 1954), pp. 49-59; and Gerhard Zwoch, Gustav-Stresemann-Bibliographie (Düsseldorf, 1953). Annelise Thimme, Gustav Stresemann. Eine politische Biographie zur Geschichte der Weimarer Republik (Hanover, Frankfurt/M., 1957) has expanded, unfortunately without documentation, her eallier valuable articles: Gustav Stresemann, Legende und Wirklichkeit, in: Historische Zeitschı ift CLXXXI, 2 (Apr.. I956), pp. 287-338; Die Locarnopolitik im Lichte des Stresemann-Nachlasses, in : Zeitschrift für Politik new ser. III, I (I956), pp.42-63; and Stresemannals Reichskanzler, in: Welt als Geschichte, XVII, I (1957),pp.9-25. 
The man who was to become one of the Republic's strongest supports, and who was clearly one of its best talents, was no friend in 1918 and I919 either of the Revolution or of the Republic. As a leading member of the National Liberal Party in the Empire Stresemann had done what he could in the Reichstag to bolster the faltering Hohenzollern monarchy on the eve of defeat, but he did not hesitate to suggest that men who could deal with the Allies be given the responsibility of government. ${ }^{1}$ Throughout the war Stresemann had continued to stress the nationalist principles of his party. As a patriot he shared the feeling of most Germans that a victorious Germany should reap its full reward in compensations and annexations. ${ }^{2}$ But he continued as well to press the Liberal demands of his party, indeed went beyond many of its members in working toward a more genuine parliamentary and democratic régime, which he recognized and accepted as the unavoidable political requirement of his time. ${ }^{3}$ Yet Stresemann did not believe in what he called "formal democracy", the simple arithmetic of ballot counting. He did believe in Liberal democracy, the partnership of electorate and competent, strong leadership. ${ }^{4}$ The Weimar Republic did not at first appear to meet that test.

In the immediate circumstances of November Stresemann, like other men in public life who felt the basic values of their society were being

1 John L. Snell, Die Republik aus Versäumnissen, in: Welt als Geschichte XV, 3/4 (1955), pp. 210-1.

2 Hans W. Gatzke, Germany's drive to the West (Drang nach Westen). A study of Germany's western wat aims during the first world war (Baltimore, 1950), pp. 21, 25. In this sense, also letter of Hugo Stinnes to the German High Command on the Eastern Front, July 19, 1915, on behalf of a wide circle of political and economic groups, including Stresemann as representative of the Bund der Industriellen: Arnold Rechberg Papers, folder $6_{3}$, Bundesarchiv, Coblenz. On the parallel annexationist enthusiasm of the left-wing Centrist Matthias Erzberger, see Gatzke, ibid., and John K. Zeender, The German Center Party during World War I. An internal study, in: Catholic Historical Review XLII, 4 (Jan., I957), p. 449.

${ }^{3}$ On this, note especially the tribute from the Left in Arthur Rosenberg, Entstehung und Geschichte der Weimaret Republik (new combined edition, Frankfurt/M., Europäische Verlagsanstalt, 1955), p. 410. Re parliamentary influence on foreign affairs, see Stresemann's speech of October 26, 1916, ReichstagDebates, volume 308,pp. 1819-23, and the favourable commentary on it by Ludwig Quessel, Unsere auswärtige Politik und der Reichstag, in: Sozialistische Monatshefte XXII, 3 (1916), pp. I I 9I-2. During the war Stresemann found himself on the same side as the Conservatives on foreign policy issues, but on such a matter as Prussian suffrage was in company with the Progressives (Fortschrittler): Stresemann to Miss Anni Michaelis, Dec. I, 1918, SP 3069/6896/13466 I-3. Annelise Thimme, Gustav Stresemann, p. 26, is sceptical about Stresemann's sincerity.

${ }^{4}$ Stresemann to Ernst Scholz, July 19, I928, SP 3163/7409/174329-4I; also undated memorandum [1928] SP $316_{3} / 7408 / 174233-8$. 
wantonly destroyed, contemplated retiring. ${ }^{1}$ Yet he did not give up the hope of keeping the National Liberal Party alive in the new state, and of preserving, if not its name, at least its idea: that is, the advancement of German interests, cultural, social, and economic through the creative leadership of the middle class. ${ }^{2}$ The hope had long been current in the Empire of forming a comprehensive middle-class party, to include as many national interests as possible. The Revolution now gave the Liberal and Conservative elements of the middle class not only an opportunity of putting these ideas of union to a test, it made such efforts a matter of political life and death.

The successor party of the National Liberals, as it finally emerged in December, 191 8, was the German People's Party (Deutsche Volkspartei, or DVP) not readily distinguishable by name or sympathies from the German National People's Party (Deutscbnationale Volkspartei, or DNVP) farther to the Right. But far from being a comprehensive group, the successor organization consisted mainly of right-wing National Liberals, and not those moderates who were congenial to Stresemann. The elements of the Right were, specifically, interests connected directly with the heavy industry of the Ruhr and Westphalia. They provided the financial backing and much of the immediate membership of the party, though of course they could be only a small percentage of the party's rank and file. ${ }^{3}$ But Stresemann, the son of a Berlin beer merchant, whose own career had been associated with the light industry of Saxony, all his life was wary of the political pressures of Western heavy industry. ${ }^{4}$ He now felt humiliated by his large degree of dependance on the funds and good will of industrialists. He was resentful of the fact of the party's constant financial embarrassment despite the vast means at the disposal of its industrial supporters. $\mathrm{He}$ resented having to appeal to them like a beggar, while receiving sharp rebukes for overlooking in this or that small way the interests of the

\footnotetext{
1 Stresemann to Siegfried v. Kardorff, Dec. II, I918, SP 3068/6892/134012; of Conservative leaders Ernst v. Heydebrand und der Lasa did retire, while Kuno Graf v. Westarp continued in party life with grave doubts: see Lewis Hertzman, The founding of the German National People's Party (DNVP), November I 918-January 1919, in: Journal of Modern History XXX, I (Mar., 1958), pp. 24-36.

${ }^{2}$ Stresemann to Georg Schmidgall, Mar. 24, I919, SP 3088/6921/137629-31; Stresemann to Siegfried Heckscher, Feb. I5, 1922, SP 3095/7008/1431 56-7; Stresemann's diary, May $25,1925, \mathrm{SP}_{3113 / 7129 / 147826 .}$

${ }^{8}$ Notable were Hugo Stinnes and Albert Vögler. J. Flathmann, representing the Kommission zur Sammlung, Verwaltung und Verwendung des industriellen Wablfonds, attended as an unofficial observer meetings of the Executive Committee of the Party: e.g. 1919, SP 3088/6921/137640, 137676-7, 137681-2, 137704-7, 137709-1 1, 137724-5.

4tresemann to Ernst Scholz, Mar. 26, 1929, SP 3164/7411/174858-62; A. Thimme, Stresemann, pp. I 5, 18-9.
} 
men who paid the piper. ${ }^{1}$ Yet he was able by and large to get along with the industrialists, not because he was a tool of the Langnamverein, but because their national and middle-class interests tended closely to coincide, as in the Ruhr crisis of 1923 , the fight for the Dawes Plan in 1924, and at Locarno in 1925. There was friction perhaps on tactics, but for a while no clash in basic aims. ${ }^{2}$

Initially the relations of the German People's Party were good with the party of the far Right, the German National People's Party, which now included many old Conservatives, Free Conservatives, PanGermans, Christian Socialists, Antisemites, Vaterlandsparteiler, and even some Progressives and National Liberals. Both parties resented the Revolution, disliked the Republic, denounced the peace negotiations, and were loud in defense of private property and the middle class. $^{3}$ Until 1920 the attitude and programmatical pronouncements of the two parties were close, particularly while the Nationalists were still under the leadership and apparent influence of their Free Conservative and Liberal elements. ${ }^{4}$ From the DNVP came a constant line of blandishment aimed at winning over the DVP to closer collaboration, and eventually to absorption. ${ }^{5}$ To parry this threat to his organization, Stresemann reiterated his party's determination to preserve the values of National Liberalism as against Conservative or Democratic groups. There might be collaboration with the DNVP, he said, but never identification. In this Stresemann had a tacit ally on the other side in the person of Count Kuno von Westarp, the rather isolated representa-

${ }^{1}$ Dispute of Stresemann with Reinhold Georg Quaatz in Fraktion, Aug. 5, 1920, SP 3090/6929/139093-8; J. Flathmann to Stresemann, May 4, I 920 , SP 3089/6927/138646-51; Stresemann to Jacob Riesser, Mar. 26, 1924 SP $3159 / 7396 / 17177^{8-9}$; Stresemann to Kurt Sobernheim, Apr. 22, 1924, SP $3159 / 7396 / 171903-4$; Stresemann to Bauer (DVP Landesverein Ostthüringen), Feb. $11,1928, \mathrm{SP} 3162 / 7406 / 173831-3$.

2 DVP Fraktion meeting, Aug. 5, I920, see footnote 1; Hugo Stinnes to Stresemann, Aug. 7: 1920, and 2 letters of Mar. 20, 1924, SP 3090/6929/139113-5, 3159/7396/171746-8, 3 IrI/71 24/146994-6; Stresemann to Stinnes, Mar. 17, and 2 letters of Mar. 26, 1924, SP $3159 / 7395 / 171736-8$, $3111 / 7124 / 147000-2$, 3159/7396/171780-2.

${ }^{3}$ Their Programmes are reprinted in Wolfgang Treue, Deutsche Parteiprogramme $186 \mathbf{I}-$ I 954 (Göttingen, 1954), pp. 106-22.

${ }^{4}$ Among these especially Clemens v. Delbrück, Adalbert Düringer, and Siegfried v. Kardorff, as well as Oskar Hergt in the phase of his Ordnungsprogramm; Prussian Constituent Assembly Debates, Sept. 26, i 9 9, vol 4, col. 440 i ff. DVP Executive Committee, Apr. I 7 , 1920, SP 3089/6928/138884-7; Stresemann's Secretary [Fritz Rauch] to Berkemeyer, Oct.

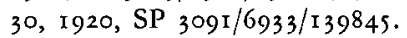

5 Berliner Tageblatt, Feb. I, I919 (a.m.); Deutsche Stimmen, Feb. 2, 1919; DVP Zentralvorstand, Apr. 12, 1919, SP 3079/6918/137190-227; DVP Executive Committee, Mar. 2, 1920, SP 3091/6936/140292-318; Hans-Erdmann v. Lindeiner-Wildau, Wir und die Deutsche Volkspartei (Berlin, I92 I), pp. 8, I0; Kuno Graf v. Westarp. Konservative Politik in det Republik I918-1932. Erstes Buch: Neue Aufgaben und Ziele. Bis zum 6.6.1920 [Manuscript], pp. 543-4 (hereafter cited as Westarp MS). 
tive of true-blue Prussian Conservatism who was winning a place of influence in the DNVP. Westarp no more wanted identification of DVP and DNVP than did Stresemann; they each did what they could to prevent it. ${ }^{1}$

Unlike most men on the Right Stresemann very soon found his bearings in the new state. He felt a compulsion to work creatively in parliament and government, even though the constitution might not be entirely to his liking. Although all his life Stresemann remained a monarchist and a friend of the Hohenzollern house, ${ }^{2}$ he was primarily the practical man of affairs who saw no way to turn the clock back. His inclination to support the Republic was confirmed by his experience of the Kapp Putsch in March, 1920. ${ }^{3}$

Although Stresemann and most of his party had nothing to do with the Putsch itself, the attitude toward the counter-revolutionaries of the DVP, as of the DNVP, was ambiguous. They dealt cautiously with the rebels as a de facto authority, and offered to use their offices for mediation with the legitimate government that had shifted to Stuttgart. Chancellor Bauer, who had no intention of dealing with the Kappists as equals, restored his full authority in Berlin with the powerful weapons of a general strike and a political campaign against the enemy on the Right. ${ }^{4}$

Both DNVP and DVP were alarmed at the tide of resentment that, in the aftermath, set in against them. Stresemann was particularly unhappy to find himself compromised in the public eye by his attempted role of honest broker during the Putsch, and resented the

1 [Fritz Rauch] to Berkemeyer, Oct. 30, I920, see p. 364, footnote 4; Stresemann to Ernst Stahmer, Feb. 4, x920, SP 3091/6935/140084-6; Stresemann to Louis Ravené, Sept. I6, 1920, SP 3089/6926/138524-5 and I38519; Kuno Graf v. Westarp to Ernst v. Heydebrand, Febr. 13, 1919, in Westarp MS, 544-5; Deutsche Stimmen, May 4, June 15, I 19 ; Walther Graef, Der Werdegang der Deutschnationalen Volkspartei I91 8-r 928, in: Max Weiss ed., Der nationale Wille; Werden und Wirken der Deutschnationalen Volkspartei I918-1928 (Essen, 1928), p. 25.

2 Stresemann to Wilhelm II, May I 3, 192 I, SP $3094 / 7001 /$ r 42 I 2 I-4; Stresemann to Eduard Dingeldey, Aug. 12, 1922, SP 3096/7016/144197-200; Stresemann to Hinzmann (DVP Bremen), Oct. 19, 1922, SP 3096/7018/144526-7; H. Gatzke, Stresemann, p. 6.

3 Stresemann's Secretary [Fritz Rauch] to Julius Curtius, Apr. I6, 1920, SP 3089/6928/ I38854-7; Stresemann to Posse, Jan. 4, 1921 , SP 3095/7004/142600-4.

${ }^{4}$ National Assembly Debates, Ma1. I8, x920, vol. 332, p. 4902 ff. On Bauer's attitude, expressed in the Cabinet and Interfraktioneller Ausschuss, Erich Koch-Weser's Diary, Mar. 23, I 920, in Erich Koch-Weser Papers (hereafter cited as KWP), folder 27 (provisional), Bundesarchiv, Coblenz. Bauer returned in triumph to Berlin, but resigned in a week following a coalition dispute concerning Vice-Chancellor Eugen Schiffer, a Democrat, who had remained in Berlin and had, like the two right-wing partics, offered to act as mediator between the Kapp and Bauer governments: Cabinet Minutes, Mar. 26, I920, in Records of the German Foreign Office (hereafter cited as GFO) $1668 / 3438 / 744165-8$, microfilm in National Archives, Washington, D.C. 
odium of being labelled a reactionary leader of the Right. ${ }^{1}$ Consequently while most Nationalists outdid themselves $e x$ post facto in repudiating the Kappists, Stresemann moved as sharply from the Nationalists. He made it clear that the DVP would work loyally with government and, given the opportunity, in government on the basis of the Weimar Constitution. The DVP sought responsibility in the state in coalition with all the positive elements in society, a grand coalition that would eventually extend through the political spectrum. Though such a grand coalition might not be possible at the moment, the DVP under Stresemann's direction was now willing to work even with the Socialists. Stresemann's bold position was not won without tension and debate within his own party, but his attitude was decisive. ${ }^{2}$

If Stresemann needed confirmation of the correctness of his tactics, it was provided by the relative immunity his party enjoyed from the popular revulsion against the Right that followed the assassinations of Matthias Erzberger in 1921 , and of Walther Rathenau in the following year. In the public mind German People's and German National People's parties, DVP and DNVP, were now clearly differentiated. Each had its bright light: Stresemann in the one, Karl Helfferich in the other. But while Stresemann was already recognized as the voice of responsibility in the state, and of reasonable fulfilment of international obligations, Helfferich was the strident voice of opposition. As the Nationalists began to feel their strength after the Kapp Putscb, they became more vocally monarchist, more sharply anti-Semitic, more uncompromisingly bourgeois and anti-Socialist. By late 1920 and in the following years they consequently became less koalitionsfäbig and more rigid in their attitude than they had appeared during the first months of Oskar Hergt's direction. Karl Helfferich, the talented economist, was one of the reasons for the change. He had rapidly built a formidable reputation as an opposition leader by his personal vendetta against Erzberger which, loaded with half-supported charges of corruption and tax evasion, ended the usefulness of Erzberger's public career. His campaign against Erzberger ended in the latter's assassination, just as his bitter attacks on the policies of Rathenau brought similarly fateful results. Rightly or wrongly Helfferich and the Nationalist Party were

${ }^{1}$ For examples of criticism, see Chancellor Müller, National Assembly Debates, Mar. 29, 1920, vol. 332, p. 4935 ff; Koch-Weser's Diary, note on Cabinet meeting of Mar. 16 , and entry for Mar. 18, 1920, KWP folder 25 (provisional).

2 Deutsche Stimmen, Sept. 26, 1920; Stresemann to Louis Ravené, see p. 365 , footnote I; Stresemann to Rudolf Heinze, Dec. 23, 1920 , SP $3090 / 693$ I/r 39429; Stresemann to Brune, Feb. 4, 1921, SP 3095/7004/142730; DVP Executive Committee, Mar. 8, 1921, SP 3094/7003/142550-65; Stresemann to W.O. Rose, Oct. 22, 1921, SP 3093/6992/140593-4; Rose to Stresemann, Oct. 28, 1921, SP $3093 / 6992 / 140595-8$; Stresemann to A.H. Tillmanns, Sept. 17, 1921, SP 3109/6997/141454-5. 
accused of intellectual authorship of the murders, with serious consequences for the effectiveness of the party. ${ }^{1}$ Though the Nationalists still gained at the polls in 1924, political bitterness in a poisoned atmosphere made acceptance of them in government unlikely for years. The nearest approach to influence in government for the Nationalists came through the accident of personal relations when the non-party cabinet of Wilhelm Cuno took office in late 1922. ${ }^{2}$ The influence that Gustav Stresemann was obtaining in the years after the Kapp Putscb was, on the contrary, no accident. It was the result of calculated acceptance of the Weimar Republic and of the Versailles Treaty, both as necessary fact. When the Cuno government failed in the compounded crisis of 1923 , the choice of successor therefore fell easily on Stresemann. Though his short chancellorship of a hundred days ended in what also appeared to be failure and personal repudiation, it is at this point we are able to take the measure of the man, and to see drawn in basic lines the problem of political leadership in the Weimar Republic. ${ }^{3}$

The man who wanted to be "the bridge between the old and the new Germany" " formed his government on a basis broader than that of any of its predecessors, extending it left from DVP through Socialists. The Socialists were willing now to work with the party and with the man with whom they had refused to cooperate less than a year before, - to that extent had Stresemann won their confidence, and to that extent did the national situation appear urgent with French and Belgian troops in the Ruhr, and the cost of passive resistance on its way to destroying the currency. ${ }^{5}$ As national unity was needed to meet the desperate foreign and domestic situation of Germany, one would have judged such a government most likely to succeed. ${ }^{6}$ But in fact, so deep were the divisions and so grave the crisis, that no democratic govern-

${ }^{1}$ Stresemann generoulsy regretted the nemesis that dogged Helfferich's tracks: Stresemann to Helferich, Aug. 3, 1922, SP 3096/7016/144154-5.

2 Martin Spahn to Hans v. Seeckt, Dec. 21, 1923 , in Hans v. Seeckt Papers (hereafter cited as HvSP), Stück 1 53, microfilm in National Archives, Washington, D.C.; Brauer to Ernst v. Heydebrand, Dec. 23. 1922, in Count Kuno v. Westarp Papers (hereafter cited as WP); Cabinet Minutes, Aug. 12, 1923, GFO r 748/3491/756364-72.

${ }^{3}$ Friedrich Stampfe1, Die vie1zehn Jahre der ersten deutschen Republik ( 3 rd ed., Hamburg, 1947), pp. 340-1; Stresemann to Walther Jänecke, Aug. I, 1923, SP 3098/71 17/145813-5; Erich Eyck, Geschichte der Weimarer Republik, I (Zurich, Stuttgart, I954), pp. 337-8.

${ }^{4}$ See p. 361, footnote 2; also, Ftitz Stern, Adenauer and a crisis in Weimar democracy, in: Political Science Quarterly LXXIII, I (Mar., 1958), p. 25, footnote 6o.

5. Stampfer, p. 341.

- Ferdinand Friedensburg, Die Weimarer Republik(rev. ed., Hanover, Frankfurt/M., 1957), p. 132; Hugh Quigley and R. T. Clark, Republican Germany (London, 1928), p. 84. 
ment, nor the dictatorship many looked for, ${ }^{1}$ could in 1923 have established national unity

Yet, if Stresemann could not unite the country, he did at least prevent it from falling apart. During his hundred days as Chancellor, Stresemann decisively and effectively met the challenges of a deteriorating situation. Much was done at this juncture in the history of the Republic to assure the stability and well being of the few good years that followed. With the support of industry (especially of his party colleague, Hugo Stinnes), assisted by the economic advisers of the government, and by the Catholic Church (among others), Stresemann ended the enormously costly policy of passive resistance to the French occupation of the Ruhr ${ }^{2}$. He directed the replacement of Germany's ruined currency by the new Rentenmark, and took steps to bring the Reicbsbank more closely into line with government policy.$^{3}$ When the governments of Saxony and Thuringia added Communists to their cabinets, Stresemann used federal power to remove them. ${ }^{4}$ While these few ministers might not have been an immediate threat to the Reich, Stresemann correctly recognized the dimensions of the Communist danger in Germany and acted promptly to avert it. Stresemann acted also, though with more caution, against the movement of Bavarian particularism that threatened even the army. The Nazi Putsch of November 9, 1923 gave him the occasion to re-establisch the lines of national jurisdiction in Bavaria. ${ }^{5}$

Though with each necessary step the Chancellor saved a situation and left a net national gain, he added to his list of enemies not only the extremists whom he squelched, but many others who resented either

${ }^{1}$ Spahn to Seeckt, see p. ${ }^{6} 67$ footnote 2; Westarp in Kreuzzeitung, Sept. 30, 1923 (a.m.), Dec. 2, I923 (a.m.); Hans v. Seeckt, Seeckt: Aus seinem Leben I918-1936, ed. Ftiedrich v. Rabenau (Leipzig, 1940), pp. 332-3,338, 345-6, 365 ; A.B. Houghton to Dept. of State, telegram 197, Nov. 6, 1923, in Records of the U.S. Dept. of State, (hereafter cited as DS), 862.00/1330, National Archives, Washington, D.C.; minute of Sept. 29, 1923 (unsigned), SP 3105/7162/154142; Stresemann to Rudolf Schneide1, Oct. 19, 9123, $\mathrm{SP}_{3} \mathrm{IO}_{0} / 7 \mathrm{I6}_{3} / 154336-7$.

${ }^{2}$ Stresemann to Crown Prince, Oct. 10, 1923, SP 3099/71 18/145901-4; Cabinet Minutes, Sept. 7, 1923, GFO 1748/3491/756590-601; DVP Fraktion, Sept. 12 and 25, 1923, SP 3159/7394/171304-1 1, 171326-31; Baron v. Geier to Fritz Mittelmann, Sept. 22, 1923, SP $3104 / 7161 / 154093-5$; interview with Cardinal Faulhaber, Sept. 23, 1923, SP $3105 / 7162 /$ /154102-7; Eduard Dingeldey to Stresemann, Sept. 26, 1923, SP 31 1 1/7124/146914-6; Stresemann's obituary for Stinnes, Apr., 1924, SP 3 1 1 2/71 27/147505-9; Martin Göhring, Stresemann. Mensch, Staatsmann, Europäet (Wiesbaden, 1956), pp. 19-20.

${ }^{3}$ Cabinet Minutes, Aug. 20, 26, 30, Nov. 5, 7, 1923, GFO 1748/3491/75641 7-31, $756445-6$, 756488-501, I749/3491/757605-10, $75761 \mathrm{r}-21$.

4 Friedensburg, p. 134; Stampfer, pp. 360 ff.; Gatzke, Stresemann, pp. 14-5; Cabinet Minutes, Nov. I , 1923, SP 3099/71 20/146153-62.

${ }^{5} \mathrm{John}$ W. Wheeler-Bennett, The nemesis of power. The German army in politics 1918-1945 (London, New York, 1954), Pp. I09-I9; Eyck, I, p. 367. 
his tactics, or his principles, or his person. The Nationalists denied him credit for his otherwise commendable fiscal policy; the "wonder of the Rentenmark" they claimed as the idea of their own economics expert, Karl Helfferich. ${ }^{1}$ More basic than the charge of plagiarism was the attempt to discredit the liquidation of the Ruhr resistance as unnecessary, unpatriotic, and operated with too much consideration for French interests. ${ }^{2}$ On the Left, the Socialists condemned Stresemann for being much tougher on the governments of Saxony and Thuringia than on that of Bavaria, and in consequence they withdrew their two cabinet members. ${ }^{3}$ As the crisis deepened rumours, more or less well founded, became strong that General Hans von Seeckt disapproved of Stresemann and felt he had to go. ${ }^{4}$

Actually Stresemann's difficulties came not only from what he did as Chancellor, but from what he had become as a statesman, and from the initial political composition of the cabinet. Many in the German People's Party had not yet come to accept the Republic, or the idea of responsibility in government together with Socialists. Their attitude after the Kapp Putsch remained what it had been before. For leadership therefore they tended to look to the Right, to the German National People's Party of Hergt, Helfferich, and Westarp. The pressure within the DVP for collaboration with the Nationalists was, however, matched by persistent Nationalist refusal to accept Stresemann as Chancellor or Foreign Minister. ${ }^{5}$ Dissidence had not reached the point in the DVP

1 Article Rentenmark, in: Max Weiss ed., Politisches Handwörterbuch (Führet-ABC) (Berlin, 1928), pp. 662-7; 1924 campaign leaflets in the Bibliothek für Zeitgeschichte, Stuttgart.

2 DNVP Landesverbandsvorsitzende, meeting Aug. 28, 1923, Berliner Tageblatt, Aug. 30, 1923 (p.m.); Stresemann's Private Secretary [Henry Bernhard] to DVP Halle, Sept. ro, 1923, SP 3159/7394/171302-3; DVP Fraktion, Sept. 25, I923, SP 3159/7394/171326-31; Cabinet Minutes, Oct. I1, I923, GFO I 749/3491/75 7057-65.

${ }^{3}$ Stampfer, p. 382 ; Stresemann remarked to American Ambassader A.B. Houghton that "while the Socialists had withdrawn from the cabinet, they were in reality not hostile. The Nationalists were in part hostile and if they had a real program and some competent men they might be dangetous, but they had neither..." Houghton to Dept. of State, Nov. 7 , I923, telegram 198, DS 862.00/1331.

4 Gordon A. Craig, The politics of the Prussian army 1640-1945 (Oxford, 1955), p. 418, footnote 3 ; Wheeler-Bennett, p. 11 io; Seeckt to Gustav v. Kahr, Nov. 5, 1923, HvSP container 22, Stück I 54 ; Erich Marcks to Ftiedrich v. Rabenau, Aug. r, 1939, HvSP container 26, Stücke 285-92; Kurt Frhr. v. Lersner to Seeckt, Nov. 7, 1923, HvSP container 19 , Stück 88; DVP Fraktion, Nov. 6, I923, SP 31 59/7394/171432-49.

5 Eglhof to Stresemann, Sept. 9, I 923, SP 31 59/7394/171 296-8; Kurt Fischer to Stresemann, Sept. 14, 1923, SP 3159/7394/171314-7; Eduard Dingeldey to Stiesemann, Nov. 9, 1923, SP 3 I I 1/71 24/146950-4; memorandum, Oct., I923 SP 3 1 59/7394/1 $71337-43$; Friedrich v. Loebell to Stresemann, Oct. I, I923, SP 3099/7 I 18/145983-4; press release, Nov. 9, 1923, $\mathrm{SP}_{3111 / 7124 / 146957 .}$ 
where serious thought could be given to eliminating Stresemann since his national following in the party remained greater than that of the opposition. The national party executive voted overwhelmingly its confidence in Stresemann, who in the next months waged a campaign that not only made the dissident elements uncomfortable, but threatened their personal political futures. ${ }^{1}$

In the midst of the cabinet crisis, a party colleague friendly to Stresemann remarked that though he was a skilful politician, he did not know how to fight for his policy in the Fraktion. ${ }^{2}$ Stresemann did know how to fight, but reserved the major portion of his energy for the national scene. From his party he expected technical advice and loyal support. When the members of the Fraktion proved inadequate as advisers and supporters, Stresemann, tired of what he called the "dog's life of party intrigue", ${ }^{3}$ moved to discipline the dissenters, exposing them to rebuke within the party as a whole, and sought to re-establish the order within the party that he had tried to get in the nation. ${ }^{4}$ Stresemann's displeasure with the Western industrialists was again apparent as he attempted to free the DVP organization from financial dependence on them in future election campaigns. ${ }^{5}$

The national gain from Stresemann's leadership in 1923 can be measured against the political cost to him of a divided party. However, in his party as in the country at large, Stresemann did not hesitate to accept unpopularity where he felt necessary policy to be at stake. He always insisted on the primacy of national and general political policy over purely party or special economic interests, regardless of the

1 DVP Landesverband Halle-Merseburg to Stresemann, Oct. 10, 1923, SP 31 59/7394/1 $71377-9$; Stresemann to Rudolf v. Campe, Nov. 8, r923, SP 3 159/7394/171459; DVP Zentralvorstand, Nov. I 8, I 923 , voted confidence in Stresemann 206 to 21, as reported in Gustav Stresemann, Vermächtnis, ed. Henıy Bernhard (Berlin, I932-3), I, p. 326; Alfred Gildemeister to Stresemann, Dec. 8, 1923, SP 3159/7395/171536-9; Stresemann to Gildemeister, Dec. ro, 1923, SP $3159 / 7395 / 171540-2$, and same date, $3111 / 7124 / 146983-4$.

2 Katharina v. Oheimb, DVP Fraktion, Nov. 9. 1923, SP $3159 / 7394 / 171465-70$.

3 “...Ich bin das Hundeleben satt - Intrigen aus der D.V.P....", DVP Fraktion, Nov. s, 1923, SP 31 59/7394/171432-49; Vermächtnis, I, p. I96.

${ }^{4}$ See footnote 1 ; also, Stresemann to Georg Wache, Mar. 17, 1924, SP 3 I 59/7395/1 71 727-8; Stresemann to Heintich Havemann, May 23, 1924, SP $3160 / 7397 / 172017^{-8}$.

5 Mahler (DVP Westfalen) to Henry Bernhard, Oct. 28, I923, SP 3 I I I/7 I 24/146947-9; memorandum Nov. 18 , 1923 , SP 31 59/7394/1 $71480-3$; Albrecht Morath to Stinnes, Feb. 9, 1924, SP 31 19/7395/1 $71663-5$; Stresemann to Stinnes, Mar. 1 7, 1924, see p. 364, footnote 2; Stresemann to Jacob Riesser, Mar. 26, 1924, see p. 364, footnote I; Stresemann to Kurt Sobernheim, Apr. 22, 1924, see p. 364, footnote I ; Stresemann to O. Päsler, Sept. 8, 1924, $\mathrm{SP} 3160 / 7397 / 172146-7$. In 1926 the DVP still depended financially on industry: Stresemann to Diekmann, Aug. 25, 1926, SP $3161 / 7403 / 173225-8$; Stresemann to Max Martin Schlenker, Aug. 14, 1927, SP 3162/7405/173602-4. 
difficulties this might bring. ${ }^{1}$ Furthermore he came increasingly to see the key for the well-being of Germany in the realm of foreign policy. ${ }^{2}$ For this reason more than any other he spoke up against any idea of forming a cabinet with what he considered to be an aggressive Nationalist Party character. ${ }^{3}$ Nor did he believe national unity could be achieved by a government based on big agriculture, big business, and the militarist organizations, as was suggested by the Nationalist leader, Oskar Hergt. ${ }^{4}$ Stresemann recalled to his cabinet colleagues a remark once made by Hugo Stinnes, who said "he liked the Nationalists well enough, but they were not a political export item."5

From the beginning of the crisis in 1923 Stresemann had seen the importance of finding an agreement with France; he saw as the prime error of Cuno's government its failure to deal directly with Paris before the Ruhr occupation; it had unwisely attempted to base its policy on relations with London and Washington. ${ }^{6}$ Moreover, as a believer "without qualification" in Machtpolitik, he was obliged to recognize the fact that Germany did not possess the military power to oppose France. Stresemann compared his policy to that of Stein and Hardenberg in preserving the integrity of the country .

But Stresemann was no blind optimist. After about half of his hundred days at the head of government he wrote that he "was very pessimistic about the future. I scarcely dare to hope any more that through negotiation we can still create a tolerable situation that will allow us to continue life within the framework of the Versailles Treaty... Our people, with their scant political education, are wavering between Communism and right radicalism". 8 So when his government fell in November, 1923, he correctly diagnosed the situation not as just another cabinet crisis, but as a foreboding of the general crisis of parliamentary government in Germany. ${ }^{9}$ Because of the growing bitterness among parties, it was becoming increasingly difficult to set up stable coalitions. Disappointed at the failure of his domestic leadership, Stresemann undertook the management of German foreign

\footnotetext{
${ }^{1}$ See p. ${ }_{3} 63$, footnote 4 ; also Stinnes to Stresemann, Mar. 20, 1 924, SP $3159 / 7396 / 171746-8$; Stresemann to Julie Bassermann, Aug. 4, I 928, SP $3163 / 7409 / 174367-9$;Göhring,pp. I 9-20. 2 Stresemann to Pauli, Feb. I4, I 923 , SP 3097/7 x 13/4 45099-102; Stresemann to W. O. Rose, SP 3098/71 16/145584-6; Fritz Stern, loc. cit., p. 25.

${ }^{3}$ Cabinet Minutes, Nov, 2, 1923, SP 3099/71 20/146165 -8, GFO 1 749/3491/75758 $3-6$.

${ }^{4}$ Cabinet Minutes, Nov. 19, $1923, \mathrm{SP}_{3099 / 7120 / 146269-82 .}$

5 Ibid.

- Stresemann to Jänecke, see p. 367 , footnote 3 ; Stresemann to Pauli, see footnote 2.

7 Stresemann to Pauli see footnote 2.

${ }^{8}$ Stresemann to Crown Prince, see p. 368 , footnote 2.

- Stresemann, ReichstagDebates, Nov. 22, 1923, vol. 361 , p. 12196, col. 2 ; Spahn to Seeckt, see p. 367 , footnote 2 .
} 
affairs in the six governments of the following six years, until his death in October, 1929.1

\section{III}

There is little question about Stresemann's talent in his role of Foreign Minister. His enemies at home could at their worst call him a traitor, while those abroad warned against the scheming Machiavellian. It would be difficult to deny him credit for insight in the formulation of policy and for skill in the arduous direction of negotiations that reestablished Germany's international respectability. ${ }^{2}$ Yet while his work in foreign affairs, and particularly its results at Locarno, received international acclaim, at home his political stock continued an erratic, but generally downward course. His efforts won him the gratitude of many Germans, but not of many in his own party, nor of many in the voting public. ${ }^{3}$ Thus while Stresemann negotiated his first major triumph, the Dawes Plan, relations with his party Fraktion reached a new low, both during the spring election of 1924 and in the subsequent fight for the Dawes Plan in the Reichstag. Stresemann felt that the Fraktion came very close to abandoning both him and the Dawes Plan legislation, ${ }^{4}$ under the influence of the Nationalists and their sustained campaign against the "second Versailles".

Yet in this instance Stresemann was able not only to throw these words back into the teeth of his assailants, bu to do them considerable harm. The economic pressure groups of the country, attracted more by the prospect of American loans than by Helfferich's rhetoric, threw their weight behind the Plan, as did the army. The Nationalists, whose support of the legislation was crucial, beset by these pressures, and by the prospect of influence through participation in government, split

1 These were the 3 governments of Marx (Dec. I, 1923-Jan. I , 1925, May 17-Dec. 17 , I 926, Jan. 28, 1927-June I 2, 1928), the 2 of Luther (Jan. I 5-Dec. 5, I925, and Jan. 20-Mar. I 2, 1926), Müller (June 28, 1928-Mar. 27, 1930): Wilhelm Dittmann, Das politische Deutschland vor Hitler (Zurich, New York, 1945).

2 Gordon A. Craig, From Bismarck to Adenauer: Aspects of German statecraft (Baltimore, 1958), pp. 70-83; Hajo Holborn, Diplomats and diplomacy in the early Weimar Republic, in: Gordon A. Craig and Felix Gilbert eds., The Diplomats 1919-1 939 (Princeton, I953), p. I71; W. M. Knight-Patterson, Germany from defeat to conquest 1913-1933 (London, I 945), p. 364; Godfrey Scheele, The Weimar Republic (London, 1946) p. 240. ${ }^{3}$ Dittmann, tables: after the I920 election the DVP lost almost steadily in electoral strength; it declined from $13.9 \%$ of total votes (65 seats) in 1920 to $8.7 \%$ (45 seats) in 1928. On the reception of the Locaino Treaty in Germany, Zygmunt J. Gasiorowski, Stresemann and Poland after Locaıno: in: Journal of Central European Affairs XVIII, 3 (Oct., I958), p. 292.

${ }^{4}$ Stresemann's Diary, July I9, I925, SP 3 II3/7129/147917-22; Stresemann to Geo1g Wache, see p. 370, footnote 4; Carl Cremer to Stresemann, Mar. 23, 1929, SP 3 I64/74I I/ I 74823-9.

${ }^{5}$ Vermächtnis, I, p. 254; Kreuzzeitung, Apr. 18, 1924 (a.m.). 
drastically on the key vote in the Reichstag, ${ }^{1}$ and faced its own leadership crisis.

Under the leadership of Count Westarp the Nationalists entered the government of Hans Luther in January, I925, there, as Stresemann hoped, to learn the lesson of moderation through responsibility. ${ }^{2}$ Temporarily collaboration with the Nationalists seemed to go well, in and out of the cabinet. ${ }^{3}$ DVP and DNVP managed to put up a joint candidate, Karl Jarres (mayor of Duisburg), in the first presidential election of that year. ${ }^{4}$ But Stresemann was most unhappy when the joint committee got Field Marshal von Hindenburg to accept its nomination for the run-off election. ${ }^{5}$ Stresemann in other ways found that cooperation of three Nationalist cabinet ministers and moderation in the leadership of the DNVP were not enough. When the draft terms of the Locarno treaties became known, the right wing of the Nationalists immediately denounced them as a sell-out of Alsace-Lorraine; a storm of protest within the DNVP overwhelmed the leadership and forced the party's withdrawal from the government. ${ }^{6}$ Stresemann's own party stuck to him this time, and indeed, after a decent waiting period of a year, the Nationalists returned to enter the Marx government in January, 1927, and to serve with three cabinet members for another year and a half. ${ }^{\text {? }}$

But the association of the Nationalists in government was not fortunate. While the illusion of moderation and responsibility lasted, one tended to forget about the hard core of irreconcilables. Initiatives within the DVP, to Stresemann's displeasure, continued to press for closer association with the DNVP. ${ }^{8}$ At the same time the right wing of

1 Vermächtnis, I, p. 524; details in author's dissertation, The German National People's Party (DNVP), 191 8-1924 (Harvard University, 1955), also Werner Liebe, Die Deutschnationale Volkspartei 1918-1924 (Düsseldorf, 1956), pp. $86 \mathrm{ff}$.

${ }^{2}$ Vermächtnis, I, pp. 376, 405, 603-8; Kreuzzeitung, Dec. 27, 1924 (p.m.); Cabinet Minutes, Oct. 15, I 924, GFO I $755 / 3491 / 7623$ I 8-22.

3 Vermächtnis, II, p. 247; Stresemann's Diary, May I 8, I925, SP 3 II 3/71 29/I47820-1; Stresemann to Walter v. Keudell, Nov. 27, 1925, SP $3113 / 7131 / 148340-2$; Chancellor Luther, Cabinet Minutes, Oct. 26, I925, GFO I836/3543/766380-5; v. Reitziner to Westarp, Oct. 30, I925, WP; Westarp to Martin Schiele, Mar. 3, I93 I, WP.

4 Vermächtnis, II, p. 48; Westarp, Die Vorgeschichte der Kandidatur Jarres, in: Kreuzzeitung, Mar. I3, I 925 (p.m.).

${ }^{5}$ Vermächtnis, 11, p. 48; Stresemann to A.B. Houghton, June 4, 1925, SP 3114/7I33/ I 49765-79; Carl v. Schubert to 17 German missions abroad, telegram $\mathrm{D}_{33} 6$, Apr. 10, I 925, GFO 228r/4525/136788-90.

6 Vermächtnis, II, pp. 207, 247-8, 284; Martin Schiele, Cabinet Minutes, Oct. 26, 1925, see footnote 3; Stresemann to Ago v. Maltzan, Apr. 7, I925, SP 31 I4/7135/149035-9. ${ }^{7}$ Stresemann's Diary, July i 9, I925, see p. 372, footnote 4; Stresemann to Walther Jänecke, Aug. x 5, 1927, SP $3115 / 7144 / 150326-31$; Westarp, in: Kreuzzeitung, July 20, 1927 (a.m.), Aug. 6, I927 (p.m.).

${ }^{8}$ E.g. the Gayl-Jarres initiative in the Prussian Staatsrat, July, 1926: Vermächtnis, II, pp. 4I 2-9; Katl v. Schoch to Henry Bernhard, July 10, 1926, SP 3100/7140/14975 7-8. 
the DNVP directed, through the extensive press holdings of Alfred Hugenberg, a campaign of vilification against Stresemann and, increasingly, against the moderate leadership of Westarp. ${ }^{1}$ In the test, on important issues of foreign policy the attempt to work with the Nationalists proved futile. In the budget debate in the Reichstag in March, 1928, Westarp attacked Stresemann's foreign policy, ${ }^{2}$ the policy that was about to produce the Young Plan and bring early evacuation by Allied troops of the Rhineland. The criticism was only a faint indication of what was brewing. The Nationalists lost heavily in the May election, and did not rejoin the coalition. Westarp was pushed out of the leadership of the party by Alfred Hugenberg who was intent on a new course aimed at nothing short of elimination of the Weimar Constitution. $^{3}$

Stresemann did not live to observe the full spectacle of the agitation against the Young Plan, which was the beginning of Hugenberg's massive campaign to win control of Germany with the help of the Stablbelm and the Nazis. His health broken, he spent much of 1928 trying to recuperate in southern climates and sanatoriums. From there he gloomily watched his party decline further in the May election, although the percentage loss of the Nationalists was greater. ${ }^{4} \mathrm{He}$ got involved in an unfortunate feud with his Fraktion over tactics and his rights as party leader. ${ }^{5}$ Meanwhile he observed Hugenberg's rise to power in the DNVP and despaired: "... the choice of Hugenberg... is a dark beginning that could end in civil war". ${ }^{6}$ There seemed perhaps some hope that the DVP now had a second chance to become the chief party of the middle class. It could perhaps attract some of the numerous

1 Stresemann to Albert Vögler, Sept. 25, 1927 , SP 31 I 5/7143/1 501 26-9; G. H. Kockelkorn to Stresemann, Mar. 14, 1927, SP $3162 / 7404 / 173451-3$; Westarp to Alfred Hugenberg, Oct. 8, 1927, Hugenberg to Gottfried Treviranus, Sept. 15, 1926, Hugenberg to Westarp, Mar. 2, and Oct. 25, 1927, WP.

2 Vermächtnis, II,p. 347; Stresemann to Robert Weismann, 1928 (no date), SP 3 I $16 / 7147 /$ I 50900-7; Westarp, Reichstag Debates, Mar. 29, 1928, vol. 395, pp. I3884-s.

3 Alfred Hugenberg, Streiflichtes aus Vergangenheit und Gegenwart (Berlin, 1927), pp. 80-1; Hugenberg to Westarp, Sept. 17, 1927, WP; Adelgunde Gräfin v. Westarp to Gertraude Freifrau Hiller v. Gaertringen. Oct. 20 1928; Stresemann to Albert Zapf, Oct. 23, 1928, SP $3163 / 7409 / 174478-80$; Friedrich Everling, Organischer Aufbau des Dritten Reichs (Munich, I 931)、 p. 51; Otto Kriegk. Hugenberg (Leipzig, 1932), pp. 69-72, 79; Hugenbergs Ringen in deutschen Schicksalsstunden, ed. Borchmeyer (Detmold, 195 I), part I, Pp. 3-4.

${ }^{4}$ Stresemann to H. Havemann, June 2, I928, SP $3{ }_{3} 6_{3} / 7407 / 1741$ I I-3. DVP dropped from $10.1 \%$ of vote to $8.7 \%$ (from 5 I to 45 Reichstag seats); DNVP fell from $20.5 \%$ to $14.2 \%$ (ro3 to 73 seats): Dittmann, tables.

5 Stresemann to Ernst Scholz, July 19, 1928, SP 3163/74c9/174329-41.

- Stresemann to Zapf, see footnote 3. 
anti-Hugenberg elements of the DNVP, such as the Christian Socialists around Walther Lambach, or the young Conservatives around Gottfried Treviranus. ${ }^{1}$ But essentially Stresemann was deeply pessimistic in 1928. As he further wrote, he saw little hope in the general situation, and he expressed concern over "the rise of Communism and the complete indifference of the bourgeoisie (ro million non-voters)". ${ }^{2}$

Within the German People's Party Stresemann noted renewed agitation against the idea of the Grosse Koalition, although no one had suitable alternatives for the present situation. "The poorest excuses are dreamed up to justify the anti-Socialist position, and the most stupid idea is vigorously advanced of allowing the Social Democrats to govern alone.... How sad that our middle class has learned so little." 3 If Stresemann needed any confirmation of his worst fears for his party and the middle class, he obtained it in February, 1929 when he returned from convalescence to attend a meeting of the Zentralvorstand. The experience was shattering to the point of making him consider the advisability of stepping down from the party leadership, of freeing the party of responsibility for his policies in the Foreign Office, and then resigning his ministerial post when important negotiations pending were completed. 4

In a long and important letter to his venerable colleague, Professor Wilhelm Kahl, Stresemann expressed the full measure of his depression, but at the same time re-affirmed his political belief. He saw a serious gap between himself and the party which no longer wanted to bear the burdens of government. Worse than the party's evident longing to escape responsibility was the fact that the DVP was ceasing to be a party of principles (Partei der Weltanschauing), and becoming "more and more a party purely of industry. The old National Liberal Party (at least) had been careful to preserve its objectivity in labor-management struggles." Finally, just as heavy on his mind, lay the recognition that none of his achievements in foreign policy seemed to mean much to his colleagues, neither the feat of Locarno, nor good relations with the United States, nor Germany's place in the League of Nations. ${ }^{6}$

${ }^{1}$ Stiesemann to Rudolf Schneider, July II, 1928, SP 3 163/7408/174305-6; Gilsa to Stresemann, Oct. 24, 1928, SP $316_{3} / 7409 / 174481-4$.

2 Stresemann to Peter Reinhold, June 2, 1928, SP 3163/7407/174106; Stresemann to Kahl, see p. 36I, footnote 2.

${ }^{3}$ Stresemann to Julie Bassermann, see p. 37x, footnote $\mathrm{I}$.

4 Henry Bernhard, Feb. 27, 1927 in DVP Zentralvorstand, Feb. 26, 1929, SP 3164/7410/ I 74694-7. Stresemann raised the question of retirement from public life as early as July $\mathrm{I} 9$, I 928 , in a letter to Ernst Scholz, see p. 374, footnote 5. Now, Stresemann to Kahl, see p. 361, footnote 2; Stresemann to G. H. Kockelkorn, Mar. 19, 1929, SP 3164/7411/ 174767-70; Stıesemann to Ernst Scholz, Mar. 26, 1929, SP 3164/7411/174858-62.

5 Stiesemann to Kahl, see p. 36r, footnote 2.

- lbid. 
Re-affirming his positive political position, Stresemann still hoped that the "party would be represented in the Reich and in Prussia, and educate the German people to support that middle-class party which showed the courage of responsibility. I am convinced", he continued, "that in the long run we will by this approach undermine the Nationalist Party which can not survive long in opposition... I see danger in driving the Socialists into opposition because that would unite Social Democracy and Communism to the grave peril of the Reich..." ${ }^{1}$ If Hugenberg succeeded in building a comprehensive coalition of the Right, that would in the long run bring about the coalition of Socialists and Communists that could permanently dominate Germany. ${ }^{2}$ Most particularly Stresemann warned against accepting Nationalists in government, lest Germany come under the domination of plutocrats like Hugenberg and the right radical blusterers who were his associates. ${ }^{3}$

\section{IV}

Stresemann, who had wanted to be the bridge between the old and the new Germany, succeeded in this task in his role of Foreign Minister, but not in that of political leader. It can not be said that this was the result of his concentrating his attention on foreign policy to the neglect of the domestic sector of affairs; the failure of his political leadership was as apparent in 1923 as it was in 1929. Stresemann failed because he was unable and unwilling to identify himself consistently with the special class interests that, with few exceptions, created the parties of the Weimar Republic. Almost from the beginning in this respect Stresemann was a leader without followers. Nor was he willing to gain followers by adopting the popular ultra-nationalist sentiments of the electorate. He preached a doctrine of moral responsibility in the national interest, which to him meant the achievement of good through positive political action, in government as far as possible, and in collaboration with as many other parties as possible. He held beneath contempt the jingos on the Right who corroded the foundations of the Republic from the irresponsible standpoint of disloyal opposition.

The disloyal opposition, however, had the last word. Though Stresemann was widely admired by many Germans who did not vote for his party, the hostile campaigns originating on the Right largely vitiated his positive accomplishments in the public eye. The public were uncertain about the merit of Stresemann's work, were impatient

1 Ibid.

2 lbid.

3 Ibid. 
for more obvious and faster results on such questions as reparations settlements and evacuation of Allied troops. Thus, deprived of the unqualified support of his own party Stresemann, one of the best talents of the Weimar Republic, a hard-working but, to the public, uninteresting man whose whole life was politics, was also deprived of acclaim as a national leader. Yet Stresemann's failure, as he clearly felt even in the deepest despondency, was not so much that of the man as of the Republic. The problem was not simply one of technical shortcomings in the Constitution, or in the nature of parties and the character of coalitions, although all were elements of weakness in the structure of the state. ${ }^{1}$ It was a problem of morale and loyalties in a Republic with few Republicans, a "monarchy in its deepest humuliation", ${ }^{2}$ a state on the brink of depression and civil strife. The heroes of the day were not chancellors and foreign ministers who made pacts with former enemies.

${ }^{1}$ Karl Dietrich Bracher, Die Auflösung der Weimarer Republik (Stuttgart, Düsseldorf, I955), pp. 68-9.

${ }^{2}$ See p. 36r, footnote 3. After Stresemann's death General v. Seeckt found it possible to sit in the Reichstag for the DVP; the party leader, Eduard Dingeldey, did not hesitate to cooperate with General v. Schleicher and Hugenberg: Dingeldey to Schleicher, Sept. 22, 1932, Dec. 30, I933, Kurt v. Schleicher Papers I7/IV/15 I, 66/13, Bundesarchiv, Coblenz; Reginald H. Phelps, Aus den Seeckt-Dokumenten II, in: Deutsche Rundschau LXXVIII, Io (Oct., I952), p. IoI9; Rabenau, pp. $651-2$. 